\title{
2: 131073278-131066531
}

National Cancer Institute

\section{Source}

National Cancer Institute. 2:131073278-131066531. NCI Thesaurus. Code C42001.

Physical location of CRYPTIC_Gene 